УДК 7.036

\title{
Visualization of the Essence (about the Creative Work of the Artist Vladimir Zhukovsky)
}

\author{
Alexandra A. Sitnikova* and Liudmila N. Zhukovskaia \\ Siberian Federal University \\ 79 Svobodny, Krasnoyarsk, 660041, Russia
}

Received 01.10.2014, received in revised form 15.11.2014, accepted 14.12.2014

This article discusses the trends of the creative activity of Vladimir Zhukovsky. His philosophicaltheoretical and art works interact and complement each other. The article argues that using visual thinking, the idea of the artist is embodied into the integrated form, and the product of his creative activity becomes a cultural value.

Keywords: artist, creative work, art, exhibition, piece of work, installation, V.I. Zhukovsky.

Research area: art history.

\section{Introduction}

Contemporaryartischaracterized byavariety of artistic trends, creative search and individual forms of expression. Vladimir Zhukovsky, the professor of Siberian Federal University, strikes a balance between a professional art historian, an artist and a professor of philosophy; his theoretical and art works interact and complement each other.

"On the one hand, Vladimir Zhukovsky perfectly understands the variety of artistic surfaces produced by masters of different cultures and eras; on the other hand, being an interesting and original artist himself, he sees some otherworldly integral value in the material shell of this or that masterpiece. Finally, as an art philosopher, Zhukovsky is endowed from on high with a unique gift to penetrate into the souls of artistic things hidden under the flesh of lines and colours, to easily read and non-trivially interpret artistic ideas, which original artists are so fond of carefully packing into the intricacies of fine geometric-compositional formulas". (Pivovarov D.V., (1999) Preface. Zhukovsky V.I. Formula garmonii [Formula of Harmony]. Krasnoyarsk, Bonus, 3).

\section{Overview of the exhibition activity and art publications of Vladimir Zhukovsky}

Vladimir Zhukovsky started his active creative activity at the beginning of 1970s, creating his own paintings, graphic sheets, 3D compositions made out of various materials. He participated in art exhibitions organized in Russian cities and abroad.

(c) Siberian Federal University. All rights reserved

* Corresponding author E-mail address: sem_dobrianka@mail.ru 
Art activity brought Vladimir Zhukovsky close to another Krasnoyarsk artist Andrey Pozdeev. In 1980 Andrey Pozdeev organized a personal exhibition of plastic works of Zhukovsky in his workshop; at the beginning of 1990s they exhibited together in Tallinn, Moscow, Saint Petersburg, Novosibirsk, Tomsk, Kemerovo. At the Second (1997) and Third (1999) Museum Biennale the installation projects of V.I. Zhukovsky "Christmas-tree-4" and "Aluminum Country" were exhibited, which aroused great interest among the audience. In subsequent years, the artist has participated in many solo and group exhibitions in Russian cities.

In 2007, in the exhibition halls of the Krasnoyarsk Museum Center the exhibition of Zhukovsky's works "Relationship" was organized. Despite the fact that exhibited plastic compositions were created at different time, their installation set is caused internally. Works made from variable materials, however, are an integrated art whole. Embodying the author's intent, the exhibited compositions are exempt from any utilitarian function and imbued with symbolic meaning; they make it possible not only to contemplate them from the outside, but also to get inside the works, enhancing human interaction with art objects. The exhibition "Relationship" is a spatial interaction of the works of the artist with each other, their relationship with the audience, as well as their dialogue with the works of Andrey Pozdeev.

In 2011, the Saint Petersburg Art Center Pushkinskaya-10 sold Vladimir Zhukovsky's personal exhibition project, "Temptation by Wisdom". The organizers of the exhibition in Saint Petersburg wrote on their website: "This exhibition project is our personal pride and a long-awaited event. One can infinitely long and objectively talk about contemporary art, its "positions, trends and situations", getting stuck in the words and losing the meaning
... But only one subjective view is enough to learn, to distinguish between true - what lives in the heart, what comes out of it, and what so irresistibly breaks out ...".

Vladimir Zhukovsky's collection "Dikzve" (2013), presented at the exhibition, organized by SibFU, gave rise to the emergence of an article of the students of the Culture Study Department in the University newspaper: "We have got to see the works of the series entitled "DIKZVE". They are extremely unusual. Vladimir Zhukovsky always surprises with the work with variable materials: using, for example, paper, clay and a scanner, he creates a living, moving world of essences. DIKZVE are "wild" animals, prisoners in the cage of the zoo. Being on the other side of the lattice, the animals may seem scary creatures in need of additional fencing. We have decided to free these animals, revealing their true, not frightening essence at all, giving them an opportunity to enjoy the happiness of free natural existence and interaction with the audience ... Especially because DIKZVE exist by themselves, they are free, and play with the audience as they please. It is most important, that they have got an opportunity to start the game and involve us into it, and, as their "parent" said, they were very happy about it".

Albums with reproductions of Vladimir Zhukovsky's works published in recent years, introduce his new art works to the audience. The album "Visualization of Selected Wisdom of Ecclesiastes" (2011) is a successful attempt not merely to illustrate the scenes of the Holy Bible, but to visualize the essence of the Bible. The artist visualized selected scenes of the Ecclesiastes, tenderly touching the depths of the legendary text, and, according to him, during the creative process "he more than once found himself working with joy with some childish smile on the face not leaving his face during many hours and days of a rather complicated activity". 
The album "Chiok" (2012) includes three collections of works - "Bunchala", "Duryndy" and "Viakushki" made with such art materials as clay, crumpled paper and coloured pencils. The "Bunchala" collection is a visual reflection on the collection of illustrations of fairy tales of Russian and world writers; the "Duryndy" collection was created with the help of crumpled pieces of paper, which symbolize talented but wayward freaks, typical goobs with unpredictable clownish behaviour. The "Viakushki" collection is integral bundles of verbal fables with graphically labeled opuses.

The "Tyto" album (2013) introduces the collection of author's works - "Dikzve", "Khakhashk", "Angel" and "MaiPa" to the audience. The materials used in the creation of the collections are wood, wire, fabric, fishing line, tempera, coloured pencils, markers, etc. "Khakhashk" collection is composed of seismic diagram reflections above the growth whirl. The works of the "Angel" collection show angelic charm and fragrance in the most ordinary things of everyday life - a broken rusted wire or a smoldered cloth, a piece of fabric with kitschy colouring or a piece of plague plastic. The latest collection of the "MaiPa" album is dedicated to the memory of parents; it is a song about the dear people who have passed away long time ago.

In early 2014, with the participation and support of the scientists of Siberian Federal University, Vladimir Zhukovsky's website was developed (http://tlenke.webnode.ru). The website has become a platform for placing the series collections of the artist created in different years of his work.

In his books and articles on the history and theory of art Vladimir Zhukovsky argues that an artist through his/her activity creates a new sensuous world, which using is embodied into a holistic form by visual thinking, and the product of creative activity becomes a cultural value.
Vladimir Zhukovsky himself is such an artist, creating a very special language out of iconic signs and symbols to transfer the essence he has grasped, and then give the viewer the right to fill it with his/her answer to the worldview question posed by the author.

Artistic creativity of Vladimir Zhukovsky is the environment in which a visible essence embodied by means of art, helps viewers to understand the artificially created language and rules of using it. The trend of convergence of the theoretical thought with artistic creativity creates a space to restore the integrity of the world perception.

\section{The attempt to dispose \\ Vladimir Zhukovsky's art \\ in the context of modern art}

Probably, a universal theory of fine arts developed by Vladimir Zhukovsky, perfectly suits to speak about his own creative works (Vladimir Zhukovsky. Theory of Fine Art. St. Petersburg, Aleteiia, 2011496 p.) Among many theoretical statements of his approach, we will try to apply several of them: firstly, the principles of argumentation based on art history regarding the subject-object language in the artist's works; secondly, the huge significance of artistic material for understanding of the essence of artistic images, because according to the theory proposed by V. Zhukovsky, a piece of art is a result of cocreation of an artist and artistic materials; thirdly, the principles of philosophical-art analysis of art works.

\section{Art traditions}

\section{in Vladimir Zhukovsky's art}

Vladimir Zhukovsky in the theory of fine arts offers to consider works of art as a text. Together with M.V. Tarasova (Zhukovsky, V.I., Tarasova, M.V. (2010). Communicative Basics of Art Culture: Monograph. Krasnoyarsk, Siberian 
Federal University, 179 p.) they offered methods of understanding the language of works of art, when one of the starting points is the analysis of object- and subject-language of an artist, where the object-language is a range of artistic traditions that have developed in the history of art, a kind of a "vocabulary set" of artistic techniques and visual images, which serve as the basis of the artist's language, while the subject-language includes artistic techniques, visual "statements" innovatively proposed by an artist in his/her works.

Of course, it is difficult to talk about artistic traditions of the author, who himself for many years has been developing and teaching numerous courses in art history - "The Art of Ancient Russia", "The Art of Ancient Egypt", "The Art of Antiquity", "Art of the $18^{\text {th }}$ century", "The Art of China", etc. Therefore, he knows well all the variety of existing artistic traditions and may potentially actualize in any of them in his works: for example, artistic traditions of Francisco Goya or Chinese graphics. Nevertheless, since we are dealing with the master who creates his works from the beginning of 1970 s, it seems necessary, at least to outline the range of artistic traditions in the art of the $20^{\text {th }}$ century, which form the language of Vladimir Zhukovsky's works.

Firstly, among VladimirZhukovsky' research papers, there are those devoted to the analysis of the phenomenon of children's drawings, where he as a researcher pays attention to the ability of children to identify the inner essence of things and phenomena in their drawings, despite the desire to "copy" the reality: "Children's drawings often do not coincide with what an adult wants to see. If, for example, a child drew a squirrel with a few diagonal hatch lines or a cock in a form of a circle with dashes around it, other children, according to the researchers, do not have any doubt about these drawings. Adults looking at these drawings, often criticize young artists that their paintings have little resemblance with real objects. But a child does not copy, but simulates objects of the reality. The essence of a squirrel for a child is in its fur, he/she makes its softness and fluffiness visible by means of a few hatch lines. The peculiar feature of a cock, according to the little painter, is the presence of a comb, beard and long, thin legs". (Zhukovsky V. (2013) Children's Drawing as a Visual Representation of an Ideal Child's Relationship with the Surrounding World. Pedagogy of Art, No. 1, 24 p., Available at: http://www.art-education.ru/AE-magazine/ archive/nomer-1-2013/zhukovski_13_04_2013. pdf). In Vladimir Zhukovsky's art works, we also find this "childish" approach to visualizing the essential features of the phenomena of life instead of the tradition of realist painting. This appeal to the traditions of children's drawings in the professional works is usually associated with "primitivism" trend: whether it is a real "inability" to draw in accordance with the realistic approach or a deliberate refusal to follow the professional rules of realistic art. Among the professional artists of the $20^{\text {th }}$ century, the assimilation with the "incoherent" abstract children's drawings is typical for the works of Joan Miro, his artistic language is inherited by the works of Vladimir Zhukovsky. In the works of Joan Miro a surreal approach is also traced- visualization of flows of unconscious, dream images that suddenly reveal the primitive essence of things to the human, the appeal to the depths of the human imagination to create artistic images, poetic convergence of the phenomena of being (a female-bird, a moonbird, etc.) - which is not less important for poetic, imagined images of Vladimir Zhukovsky drawn from dreams (a way to communicate with the unconscious, the archetypal in the inner world of the human).

Since a large part of Vladimir Zhukovsky's art includes art objects, kinetic sculptures of all kinds of materials(initially not aimed for art 
works), then we should also mention works of Alexander Calder, an American sculptor, famous for his sculptures, which are set in motion - slow and quiet, and not aggressively assertive - from a waft, a touch, an electric action. A special feature of Vladimir Zhukovsky's works is their tactile quality, often many of them can be touched, as a result, they are set in motion, again barely perceptible - a flutter; a rotation in order to "show off" in front of the audience from all sides, and even if the movement is programmed by a mechanism, it is barely perceptible - as, for example, in the kinetic object "Remembering Doriphor", where an electric motor with one turn per minute is buzzing, but does not set an object in motion.

It is clear that a wide range of the objectlanguage artistic techniques that Vladimir Zhukovsky "uses" in his works, is much more representative, but at least we get an idea what aesthetic and philosophical spaces in the art of the $20^{\text {th }}$ century are close to the master's art.

\section{Specificity of the Material Status of Vladimir Zhukovsky's Works}

One of the notable features of Vladimir Zhukovsky's works is attractiveness and intriguing nature of the material he works with. The artist works with a variety of materials and techniques, which are often not considered to be art ones.

Initially, of course, we should mention wood. Vladimir Zhukovsky masterfully works with wood. In his creative works, there is traditional wood carving with, for example, pagan ornaments. No at the Department of Art and Culture Study of Krasnoyarsk State University he delivered a special course for art students "Art Carving". As a result, the students had an opportunity to bring original carved aesthetics of solar and vegetative ornaments in the design of their classrooms. Also, many art objects in his works are made of wood.
It is a unique fact that Vladimir Zhukovsky may start working with the wood material of almost any quality: ranging from rare wood material to simple "dacha" woodpile. Here, we can resort to a metaphor and say that the artist like Mister Geppetto sees some character in the wood material, that he can get out of it, and animates the material.

Another materials used by the artist Vladimir Zhukovsky are household items: brushes, ropes, pans, fabrics, polyethylene and the like. The artist pulls these materials out of the household context, deprives their utilitarian function, and draws in the art space, giving them life as characters of his work, creating imaginary creatures, which have started to live their own life: dissolve in the sunlight, associate with familiar anthropomorphic visual images, get started into motion by a gentle touch or due to hanging in the air (the most appropriate approach to exhibiting the author's works), showing different "faces" of their being, etc. In addition to household items, the artist uses both traditional art materials (paper, clay, papier-mâché), and rare materials, the behaviour of which he explores in the process of working with them: for example, the plastic for the manufacture of dentures, lead, etc. Ultimately, when dealing with the works of the artist, the viewers often wonder: How is it done? What is it made of? The viewer is curious about the material, which was used to give birth to this or that fictional character. Most often it is impossible to determine this, and it is the skill of the artist: the material is completely reborn in the creative process, it becomes a synthetic being, when the actions of the creator are inseparable from the "clay" the artist works with.

Actively studying new technologies starting approximately in the 2000s, the artist has turned to the modern technology - computer graphics, 
where he combines traditional graphics created on paper with digital image processing in Photoshop.

\section{Special Features of the Subject-Language of Vladimir Zhukovsky's Works}

As it was already mentioned, we can determine two types of works in Vladimir Zhukovsky's art: pieces of art and graphical works.

Pieces of art represent some imaginary creatures associatively resembling anthropomorphic or zoomorphic creatures, but, in fact, are imaginary beings - with their own organic and demeanor. One of the artist's creative intentions is to create a visual image of the non-existent, the unbelievable. Sometimes these creatures are the material embodiment of the creative imagination and imagination in its pure form (some buglike, snakelike, birdlike characters, etc.), sometimes they are connected with stable visual images revealing some phenomenological depths of certain phenomena. Thus, the common stable images in the works of V. Zhukovsky intersect with religious visual scenes-Crucifixion, Madonna, angels. Numerous variants of angels in the artist's works reveal his desire to visualize the invisible essence: of course, in religious art, there are variants of the canonical images of angels - the six-winged seraphims, the four-winged multi-eyed cherubims, etc. - but, in fact, angels are creatures unimaginable for the human vision. Also among pieces of art there are visual options of other Bible characters - for example, John the Baptist, or the artist visualizes rare biblical subjects - "Washing of the Feet". Crossbreeding of the author's technique of working with household materials and religious themes (the beheading of John the Baptist is done on an ordinary plastic plate, and washing of the feet in a common plastic basin, everyone uses for household needs) makes us think about the merger of the sublime religious history and the everyday life of a modern man. In graphics V. Zhukovsky also often works on visualization of unpopular religious texts - such as "Ecclesiast" or "Songs of Solomon", when he creates visual images of the Biblical essence, for which there are no strict canonical versions of images, and even no unambiguous verbal interpretations.

Another line appearing as a leitmotif in many works is two-facedness. Typically, the object characters have two opposite faces: smiling angry; calm - tearing themselves apart; dressed skinned; female - male, etc. It can be assumed that the visual motif is related to the philosophical thoughts about edges and sides of human life when harmonious and tragic often replace each other, just as the viewer observes the one and then the other side of the work. Also, it is worth mentioning as a recurring creative motif a number of art objects that reproduce weapons - pistols, rifles, tanks - by means of a variety of materials (papermache, paper, plastic, foam, leather, wood). This is the items of children's boyish games (in this respect, art is the ability to play throughout life, and not to leave the game beyond the threshold of childhood, not surprisingly, many thinkers have come to the conclusion that "life is a game"); the items of war, military life, which lose their deadly force, being made of household materials, embroidered and painted. This series of works reminds of the works of another contemporary Russian artist Dmitry Tsvetkov, among his pieces of are there is a series of sewed together pistols and rifles. Perhaps, the works of V. Zhukovsky and D. Tsvetkov can be united by the metaphor about visualization of the "soft power" of art.

Regarding graphic works of V. Zhukovsky, let us pay attention to the fact that his graphics often offers a synthesis of verbal and visual images, regardless whether it represents the songs of Vladimir Vysotsky, Biblical texts, fairy tales or words randomly selected from a dictionary. Here 
the artist's desire to find a visual version of the unimaginable is also demonstrated. In the text, the author selects either such episodes, which are originally difficult to imagine: for example, in the collection "Bunchala", the following phrase is visualized: "Voron Voronovich put the old man under his wing. When the old man fell asleep, they both fell down and died" - it is initially difficult to imagine how this action looks like. He either invents words by summing the parts of different words or selects a word the meaning of which is known only to the dictionary makers: for example, the series "PLIAMON" stands for "Dancing Monster", "LESIZOKH" - "The Ladder of Omar Khayyam Quotations", or in the series "SK i SK" all works are signed with the words from the dictionary, starting with the letters "Sk" ("Skarednaia skrynia i skatnyi skrap"). As a result of the creation of new words, it is not the name that explains the visual image as it is usually done, but rather a visual representation suggests ways of understanding names, in particular. This is especially true in respect to the biblical sayings or lyrics: as the deep philosophical meaning of the saying is not always clear, the visual image reveals it, suggests ways to interpret it.

Of course, the artistic techniques, characteristics of the visual language, the semantic content of Vladimir Zhukovsky's works given herein, are not exhaustive. As it was indicated in the subtitle, this is just an attempt of the disposition of the artist's creative works in history, at least, the art of the $20^{\text {th }}$ - beginning of the $21^{\text {st }}$ century, while further studies of the artist's works can be connected with the philosophicalart analysis of the individual works and series.

\section{References}

1. Jose Luis Sert. Joan Miro (2004) (translated into Russian) Moscow, Art-rodnik, 95 p.

2. Lavrentiev A. (2013) Where Rodchenko meets Calder and Calder meets Rodchenko. Art and Literature Scientific and Analytical Journal, available at: http://elibrary.ru/download/17853524.pdf

3. Official website of the artist V.I. Zhukovsky: http://tlenke.webnode.ru

4. Petrova, E.N. (2004) Joan Miro, 1893-1983: monograph. Palace editions, 143 p.

5. Semenova, A. A. (2007) Otnoshenie k "Otnosheniiu" [Attitude to the "Attitude"]. Novaia universitetskaia zhizn' [New University Life], (9). 6.

6. Tuchman P. (2001) Calder's Playful Genius. Smithconian, pp. 82-90.

7. Zhukovsky, V.I. (2011) Vizualizatsiia izbrannykh mudrostei Ekklesiasta [Visualization of Selected Wisdoms of the Ecclesiast]. Krasnoyarsk, 50 p.

8. Zhukovsky, V.I. (2011) Teoriia izobrazitel'nogo iskusstva [Theory of Fine Art]. SaintPetersburg, Aleteiia, $496 \mathrm{p}$.

9. Zhukovsky, V.I. (2013) Tyto. Krasnoyarsk, 94 p.

10. Zhukovsky, V.I. (2012) Chiok. Krasnoyarsk, 84 p.

11. Zhukovsky, V.I. (1999) Formula garmonii [Formula of Harmony]. Krasnoyarsk, Bonus, $206 \mathrm{p}$.

12. Zhukovsky, V.I., Tarasova, M.V. (2010) Kommunikativnye osnovy khudozhestvennoi kul'tury: monografiia [Communicative Basics of the Art Culture: Monograph]. Krasnoyarsk, Siberian Federal University, $179 \mathrm{p}$.

13. Zhukovsky, V.I. (2013) Detskii risunok - nagliadnoe predstavlenie ideal'nogo otnosheniia rebenka s okruzhaiushchim mirom [Children's Drawing as a Visual Representation of an Ideal Child's Relationship with the Surrounding World]. Pedagogika iskusstva [Pedagogy of Art] No. 1, 24 p., 
available at: http://www.art-education.ru/AE-magazine/archive/nomer-1-2013/zhukovski_13_04_2013. pdf

\title{
Визуализация сущности \\ (о творчестве художника В.И. Жуковского)
}

\author{
А.А. Ситникова, Л.Н. Жуковская \\ Сибирский федеральный университет \\ Россия, 660041, Красноярск, пр. Свободный, 79
}

В статье рассматриваются направления творческой деятельности В.И. Жуковского, философско-теоретические и художественные работы которого взаимодействуют и взаимодополняют друг друга; утверждается, что с помощью визуального мышления идея художника воплощается в цеелостную форму, а продукт творческой активности становится культурной ценностью.

Ключевые слова: художник, творчество, изобразительное искусство, выставка, произведение, инсталляиия, Жуковский В.И.

Научная специальность: 17.00.00-искусствоведение. 